\title{
Library Services to the Graduate Community: The Role of the \\ Subject Specialist Librarian
}

\begin{abstract}
A program of dynamic, interactive information service in the academic library is facilitated with direct contact between the user and the subject specialist librarian. This librarian can perform a number of important services: establishing contact with user groups; selection of materials and collection development; instruction in library use; provision of current awareness, reference, and bibliographical services; serving as a library "ombudsman" for users; and bringing user perspectives to the technical service departments of the library.
\end{abstract}

$\mathrm{T}$ HE ACADEMIC LIBRARY must be a part of an interactive system in which librarians assist in the utilization of information resources and information. The library must have a philosophy of service which requires librarians to reach out to individual users or groups of users in order to: (1) identify their information needs; (2) identify the problems they encounter in attempting to fulfill these needs; (3) convey and demonstrate the range of services available in the library; and (4) bring back to the library an appreciation and understanding of user needs and the meth-

Thomas J. Michalak is chief, Science and Engineering Division, Columbia University Libraries, New York. This article is based on a talk given at the ACRL University $\mathrm{Li}$ braries Section program on library services to the graduate community at the ALA Conference in San Francisco, July 1, 1975. At that time the author held the position of subject specialist for economics and political science, Indiana University Libraries, Bloomington. ods and tools of scholarship and instruction.

How can this kind of philosophy of academic library service be put into action? One way to develop an interactive, dynamic information service in academic libraries is to provide direct linkages with user groups through subject specialist librarians.

In recent years there has been considerable interest in subject specialist librarians or, as Maurice Line prefers to label them, information officers. ${ }^{1}$ In 1968, at the ALA Conference in Kansas City, Robert Haro, Helen Tuttle, and Alan Taylor presented divergent views on the role of subject bibliographers in university libraries. ${ }^{2}$ At the ALA Conference in Dallas in 1971, the ACRL Subject Specialists Section sponsored a program on the "Subject Specialists in Academic Libraries," at which Eldred Smith, Alan Taylor, and Thomas Kirk discussed the place and role of subject specialists in college and university libraries. We now know that subject spe- 
cialists "have arrived" insofar as they have become the subject of dissertations and several fellowship grants by the Council on Library Resources. In June 1975 the Council on Library Resources announced an "Advanced Study Program for Librarians" to further the development of subject specialists for the nation's research and academic libraries.

Increasing numbers of British and American university libraries have adopted the practice of providing linkages between academic departments and the library through subject specialists, information officers, and liaison librarians. What is important is the function, whatever the terminology, and in this article the term, librarian, will be used for this kind of librarian. Through the liaison function of this librarian, the needs and problems of library users and the services of the library are brought together. The librarian is assigned the responsibility for communications with a specific academic department or group of academic departments. The librarian has training, usually at the graduate level, in one or more of the disciplines represented by the academic department(s); is possessed with communication skills; and has the self-confidence so as to contribute to the research and teaching objectives of academic departments. In addition, this librarian has responsibilities such as book selection and collection development, reference services, bibliographical control, instruction in the utilization of library resources, the development of current awareness or selective dissemination of information (SDI) services, and what can be termed an "ombudsman" function. $^{3}$

Acting in such a capacity, the librarian does not wait for the user to come to the library but actively seeks out the user, not only in the library but also in departmental offices or classrooms. The librarian has a threefold responsibility: first, to identify and communicate the needs of the users in the development and implementation of library operations, services, and policies; second, to identify and interpret bibliographical and informational resources to the users; and, third, to interpret library operations, services, and policies to the users.

\section{Establishing Contact}

Since the librarian is responsible for the delivery of certain kinds of academic library services to discrete groups of users, the librarian initiates the contact with the user. Before a new faculty member sets foot on the campus, the librarian should have made first contact. Even preferable to this would be the inclusion of the librarian as part of the interview process for prospective faculty members. In any case, contact should be made before the faculty member's arrival in order to get a clear perception of the faculty member's fields of research and teaching interests and, more practically speaking, to solicit reserve or reading lists in advance of arrival. When the faculty member arrives, the librarian should call on him or her in order to explain the library's services and the librarian's role in them.

Similar practices can be followed with new graduate students. At Indiana University, the graduate students in the Political Science Department have established a two-day orientation program for new students, and the librarian meets with these students and conducts a facilities tour. A graduate student's life revolves around the academic department. Establishing initial contact with the liaison librarian personalizes the library's services, and the student becomes aware that there is a librarian connected with the academic department to assist at the proper time.

\section{Book Selection and Collection DEVELOPMENT}

A major responsibility frequently assigned to subject specialists is that of 
selection and collection development for specific disciplines or academic departments. This responsibility involves not only selection of current materials, but also retrospective purchasing; preservation activities; weeding; decisions regarding conversion of materials into other formats such as microfiche, binding, and replacement of missing materials; and frequently, particularly in the case of librarians with geographical area responsibilities, establishing contacts in foreign countries for the purposes of exchange and/or purchasing.

The librarian cannot do selection and collection development in isolation. Collection development requires the preparation of profiles of the institution's curriculum within the scope of the librarian's assignment, the identification of areas of overlap among disciplines, and the identification of cross-disciplinary areas in order to establish collection policy in conjunction with the activities of users and the objectives of the university. Collection development also requires the development of a profile of research interests of the faculty and the students, the identification of their subject interests, and the methodological approaches employed. Existing resources and collections of the library and other units within the university, for example, clandestine or fugitive reading rooms and numerous caches of material stashed in the most unlikely places on the university campus, must be identified, evaluated, and, if possible, brought under bibliographical control in some way. Strengths, weaknesses, and gaps must be identified, and all these factors must be brought together into a coherent collection policy to guide the decisions of librarians and others in the selection and collection development process. ${ }^{4}$

The librarian must develop sensors as to the needs of users and the goals and objectives of the library's collections. In developing selection and collec- tion criteria and priorities, the librarian consults with members of the faculty and the chairperson of the academic department to get an idea of current teaching and research and future directions of the department; examines dissertations produced by students in the department; examines circulation and reserve lists; reviews the collections; and, in short, seeks any means which will give some insight into the curricular or research interests or activities of the librarian's publics.

In addition, newsletters and journals are primary sources for the identification of relevant material and, more importantly, for keeping abreast of changes and new directions within the field and the development of subfields within disciplines. The librarian in this active role develops the kinds of sensors which ultimately contribute to the satisfaction of the needs of the clientele. Through liaison and interaction with users, the librarian is aided in establishing appropriate collection policies and priorities.

\section{INSTRUCTION}

The subject specialist librarian can play a vital role in the instruction of all levels of users-faculty, graduate students, and undergraduate students. Instruction should be interpreted to mean teaching or guiding users in utilizing or obtaining a wide range of materials needed for instruction and research.

Arranging a presentation on the Social Sciences Citation Index, explaining the use of a new reference tool to an individual user, bringing a recent acquisition to the attention of a student, helping a user become aware of the extension of the library's resources through the Center for Research Libraries or other cooperative programs are a few examples of instructional activities which are part of the daily routines of librarians.

Instruction can also be more formalized. The development of credit or non- 
credit courses in many libraries is both a response to expressed user needs and an anticipation of the needs of students. Through instructional activities, the librarian develops additional insights into the problems of users and their information needs, insights into how people go about their work, and useful feedback on whether the library is meeting information needs, particularly in ways which are not frustrating to the user. Formal instruction can be effective in bringing to the student a wide range of resource materials, methods of access to resources, the intricacies of access tools, and the mysteries inherent, so it seems, in the delivery of library services.

Librarians can best perform the instructional function in coordination with academic departments by the development of formal courses of instruction in the bibliographical and research resources of a specific discipline. Ideally, these courses will be for credit in the student's major department, particularly as the department then views the training in bibliographical and research resources as part of the methodological training of graduate students. This affects the seriousness with which students will approach the subject matter.

At Indiana University, for example, there are formal courses offered in chemical literature, art history, political science, Latin American studies, Slavic studies, and African studies. The latter course is a required course for all students in the African Studies Program while the other courses are optional. The range of courses which are possible includes all disciplines, providing the talents of librarians and the support of academic departments are present. Such instruction need not be limited to graduate students, but can include undergraduate majors as well.

Other forms of instruction may include developing specific lectures or presentations to meet information needs in specific courses, for example, United Nations documentation, legislative tracing, census data, nineteenth century English literature, and folklore. The stimulus for this form of instruction can come either from the librarian or from the faculty member or teaching assistant. A certain diffusion of innovations takes place, and the successful librarian may be called upon by faculty members to quickly expand the repertoire of library or bibliographical research lectures.

\section{Current Awareness Services}

An important service which librarians can render to faculty and graduate students is the development of current awareness or selective dissemination of information (SDI) services. Through collection development, the librarian is in an enviable position of being able to "keep up" on the literature. The librarian can thus assist users in the arduous task of "awareness." This service can, of course, take many forms, ranging from highly sophisticated systems utilizing MARC tapes or other machine-readable records, to the very simple and inexpensive mimeographed acquisitions lists depending on the availability of systems, dollars, and time.

The system developed to serve users in the departments of economics and political science at Indiana University is at the simple and inexpensive end of the spectrum. Once a month a list of recent acquisitions is published in each subject. These lists are selected and compiled from catalog and other records and are typed in the librarian's office. Copies are reproduced in departmental offices and distributed to faculty members and interested graduate students. Copies are also made available in the library to anyone interested, and a limited mailing list consisting primarily of ex-students and faculty members is maintained.

In order to assist faculty members in 
keeping abreast of periodical literature, each faculty member may submit a list of up to fifteen journals for which he or she wishes to receive the contents pages as journals are published. As the library receives the journals, title pages are photocopied and distributed. In 1974-75, approximately 2,800 title pages were distributed to participating faculty members in the departments of economics and political science.

In addition to these modest methods of current awareness, delivery services for books and periodical articles have been provided to faculty members in economics and political science since the fall of 1972. A faculty member either sends to the librarian a request slip or leaves it in the departmental office where a student will pick it up and bring it to the library for processing. These requests are processed by the subject specialist's staff, and the book or photocopy of journal article is delivered to faculty mail boxes in the departmental offices. Delivery is usually made within two or three days of receipt. If the material is not immediately available, the request is put in a queue, and as soon as the material becomes available, the material is dispatched. Hence faculty members have come to realize that, once an item is requested, they will receive it in due course. The cost of this service is modest. Clerical costs for retrieval and delivery average 51 cents per transaction. The photocopy charge averages 38 cents per article. This latter figure, however, does not include personnel costs in photocopying, but only machine costs. The photocopy charges are paid from book funds. The service has proved so beneficial to the Political Science Department, that the department supplied $\$ 1,000$ to cover part of the clerical costs, which are about $\$ 1,700$ a year. The service is justified in terms of user satisfaction, and, more importantly, in terms of the economics of the faculty member's time.
The development of machine-readable data bases opens up a whole new area for interaction between librarian and user. The complexity of data bases and the fact that few individuals can master more than several indicates that utilization of these new resources may require the mediation of a librarian. Where subject specialists or information officers exist, no doubt the responsibility will be seized by them. As Maurice Line has stated: "The increasing complexity of information systems means that all but the most persistent and sophisticated user will at times, and probably increasingly, find difficulty in using them effectively, or at all."

The librarian will have to become familiar with relevant data bases in the area of specialization in order to assist faculty and students in the choice of data bases and the construction of searches. In marketing the availability of such data base packages offered by Lockheed and Systems Development Corporation, the academic library can utilize the existing contacts with academic departments already available in subject specialist librarians. After all, computerized data bases are merely another tool in the arsenal of available information resources, and it is the librarian's responsibility to bring the tool and the user together.

\section{REFERENCE AND BIBLIOGRAPHICAL SERVICES}

Another important function that librarians perform is to provide reference and bibliographical services to faculty members and graduate students. Without getting into a discussion of the most appropriate place for subject librarians in the library organization, i.e., reference, acquisitions, or independent, one may simply state that they have an obligation and responsibility to provide reference services to members of the faculty and the students in the departments which they serve and, further- 
more, to anyone who has a problem in the area in which they specialize. One distinction between subject specialists or information officers and bibliographers is that the former have a responsibility to share their knowledge and experience with others through reference, bibliographical, and other services.

The accumulation of experience and knowledge of materials and resources in a discipline are considerable assets in any academic department and must be made available to faculty and students, not in a passive role, but in an active one in which reference and bibliographical services are made available conveniently to users. This may mean that the librarians may have to be available at the times their prospective clientele use the library rather than at hours of their own choosing. In this regard, the placement of the subject specialist librarians in the service, or traffic, pattern of the library can be significant. If the library is merchandising its services, then it is imperative that the subject specialist librarians be located where the user can readily identify their existence and their services.

The librarian as subject specialist has a command of the available information resources within the university and beyond the community as well. In this capacity, the librarian does not merely work with the user in the identification of single resources, but helps the user identify the infrastructure of information relevant to a specific research project-bibliographical, data, and other resources. In assisting graduate students, the librarian can make a significant contribution in the development of appropriate topics for dissertation research, and it may be appropriate for the librarian to serve on a graduate student's research committee.

The librarian as a bibliographical and research resource is available not only to students, but also to members of the faculty. The librarian can become an important part of a research team by the identification of appropriate materials and sources for faculty research. In practice, few librarians have the time, given their other responsibilities, to stimulate faculty members to seek their active participation in research projects, and perhaps it is unrealistic to expect a great deal of activity in this area. But, nonetheless, the librarian should consider the extension of library services in this area and should attempt to make the library's services known, even if it is no more than the provision of delivery services for books and periodical articles. However, the liaison of librarians with faculty research projects can have a payoff in the provision of additional resources through research grants. The librarian as part of the research team can be a valuable asset in the conduct of research, and benefits from such a liaison can accrue to both parties.

\section{OMbUdSMAN}

In conveying services to faculty members and graduate students, the librarian has the responsibility to interpret library operations, policies, and services to the users. The liaison role will often develop into a sort of library "ombudsman" function for members of the academic departments. Bibliographical, research, and service problems which users encounter will often be brought to the liaison librarian. The librarian must exercise discretion and tact so as not to make unreasonable demands or create undue strains on colleagues. But the librarian should do all that is possible to mediate a user problem in attempting to meet critical information needs of the library's clientele.

As users experience a receptivity and sympathy for their very real and personal information problems, the "ombudsman" role adds a significant dimension to the quality and personality of the library's services. On the other hand, users 
must come to a better understanding of the library's problems, objectives, and priorities. The liaison librarian is in a good position to assist in educating the library's users in this regard. A librarian who has the confidence and respect of users can be persuasive in explaining the rationale behind a library policy. These librarians can make an important contribution in conveying to library users the nature of cooperative arrangements which are becoming increasingly important even in the largest and richest libraries. The faculty and students need to be informed of the existence and resources of such cooperative enterprises as the Center for Research Libraries. When a library enters into cooperative arrangements, the subject specialist librarians can be responsible for supporting these efforts and conveying their importance, use, and means of access to their academic departments.

Another example of this "ombudsman" activity is the assistance in the retrieval of materials from the technical processes pipeline. Graduate students often have need of the latest materials in their field, usually stemming from a professor's recommendation, particularly around the time for comprehensive examinations; or they may be attempting to "one up" their professor. While libraries usually make materials available on a "rush" basis, obstacles to their retrieval often present themselves to the requesting user; this leads to much grumbling and complaining on both sides. The subject specialist librarian should know the "ins and outs" of the technical departments and can be of great assistance in retrieving needed items. Furthermore, these user contacts are important sources of feedback about the materials students are using and demanding.

By this "ombudsman" function the librarian can be attuned to the problems which users encounter and can convey the nature of these problems to others in the organization in a manner which is collegially supportive of the library's efforts to enhance and increase user satisfaction and, consequently, the sense of professional pride and accomplishment on the part of each member of the library staff. The liaison librarian should, of course, also report back to members of the library staff instances and expressions of user satisfaction and appreciation.

\section{BibliogRaphical CONTROL AND Other Technical Processes}

Within the area of bibliographical control and other technical processes, the liaison librarian can play an important role in interpreting the needs of library users. It may be unrealistic to expect librarians acting in this capacity to undertake cataloging assignments, given the constraints of their other responsibilities. Nevertheless, the subject specialist librarian has the responsibility to work with the technical and support group in bringing user experiences and user perspectives into the technical departments. Bibliographical control is an area where extensive cooperation between the subject specialist librarian and the catalog librarian can be developed into a relationship which is mutually beneficial. The subject specialist can convey bits of information regarding the subject matter of the discipline, changes in emphasis, user problems, and cataloging priorities in light of immediate informational needs, to cite just a few examples. The cataloger, on the other hand, can bring to the subject specialist's attention changes in subject headings, cataloging rules, departmental procedures, and gaps in the collection, as well as errors which may occur in the selection process, particularly regarding sets and translations.

A specific example in the area of cataloging can best illustrate the development of collegial cooperation. Indiana University has an active student Pub- 
lic Interest Research Group, called InPIRG. Students in this group complained that they could not find some "Nader" reports in the card catalog. This complaint was reinforced by the faculty sponsor of InPIRG. A bibliography was prepared of all the works that could be identified as being, in any way, connected with Ralph Nader or his organizations. The problem was brought to the economics and political science cataloger. The cataloger was sympathetic to the students' problem and proposed that, using the bibliography, appropriate added entries be made for all those publications which did not have Nader, Ralph as a main or added entry. Each time a new "Nader" item is selected, it is flagged; and, when necessary, the cataloger makes the appropriate added entry.

Examples of this kind of cooperation, particularly in the area of acquisitions and serials as well as bibliographic control, are legion. The point to emphasize is that cooperation and liaison must be internal as well as external. In the development of interactive library services the librarian with liaison or communication responsibilities, works collegially, not only with users, but also with members of the library staff. The perspectives and contributions of colleagues with the library's technical departments are vital to the delivery of interactive library services.

\section{ConcLusion}

Through the development of linkages between academic departments and the library, the faculty and the students view the library as an organization which is making significant contributions to the missions of instruction and scholarship. The administration of the university learns more about the effectiveness with which the library operates and the level of satisfaction the users experience from faculty and students than through arguments and elaborate presentations by the library administration. Where interactive and responsive services exist, the library is likely to fare reasonably well in periods of austerity.

In an era of budgetary stagnation and retrenchment, subject specialist librarians should be able to make additional contributions. They can convey their perceptions of the needs of the library's publics in the reevaluation of library services and operations. They can contribute the user's view as to the effectiveness and need for certain services. Second, they are in an ideal situation to evaluate honestly and refine the priorities of their collections and make whatever adjustments the fiscal situation warrants, not arbitrarily, but in view of the curricular and research needs of the academic departments and the daily informational needs of their publics. Last, these librarians can make an additional contribution by interpreting library policies regarding collection development and library cooperation and sharing to users. Because of their regular user contacts, it should be their responsibility to communicate the importance of these programs and how they can be used to advantage.

\section{REFERENCES}

1. Maurice Line, "The Case for Information Officers," in John Lubans, ed., Educating the Library User (New York: Bowker, 1974), p.383-91.

2. Robert P. Haro, "The Bibliographer in the Academic Library," Library Resources b Technical Services 13:163-69 (Spring 1969); and Helen Welch Tuttle, "An Acquisitionist Looks at Mr. Haro's Bibliographer," Library Resources \& Technical Services 13:170-74 (Spring 1969).

3. The following are relevant articles on subject specialists in academic libraries: Cecil K. Byrd, "Subject Specialist in a University Library," College \& Research Libraries 27: 191-93 (May 1966), describes the program established at Indiana University; Kenneth Humphreys, "The Subject Specialist in National and University Libraries," Libri 13: 29-41 (1967); A. Holbrook, "The Subject Specialist in Polytechnic Libraries," New Li- 
brary World 73:393-96 (1972); W. L. Guttsman, "Subject Specialisation in Academic Libraries: Some Preliminary Observations on Role Conflict and Organizational Stress," Journal of Librarianship 5:1-8 (Jan. 1973), describes many of the organizational problems arising from the establishment of subject specialists; Ann Coppin, "The Subject Specialist on the Academic Library Staff," Libri 24:122-28 (1974), provides a brief survey of the literature on subject specialists; Charles A. Crossley, "The Subject Specialist Librarian in an Academic Library: His Role and Place," Aslib Proceedings 26: 236-49 (June 1964), provides an excellent list of objectives for subject specialists; Selby U. Gration and Arthur P. Young, "Reference-Bibliographers in the College Library," College \& Research Libraries 35:28-34 (Jan. 1974); Eldred Smith, "The Impact of the
Subject Specialist Librarian on the Organization and Structure of the Academic Research Library," in Evan Ira Farber and Ruth Walling, eds., The Academic Library; Essays in Honor of Guy R. Lyle (Metuchen, N.J.: Scarecrow, 1974), p.71-81, summarizes the results of a survey conducted while $\mathrm{Mr}$. Smith was a CLR fellow; Peter Woodhead, "Subject Specialisation in Three British University Libraries," Libri 24:30-60 (1974), describes the arrangement at the University College, London; University of Leeds; and the University of Bradford.

4. For a good survey of the collection development role see J. Periam Danton, "The Subject Specialist in National and University Libraries, with Special Reference to Book Selection," Libri 17:42-58 (1967).

5. Line, "The Case for Information Officers," p.386. 